\title{
Ancient Israel: A Way of Organizing Our Ignorance*
}

\author{
(1) Niels Peter Lemche \\ University of Copenhagen
}

Fecha de recepción: 5 de julio de 2018. Fecha de aceptación: 1 de agosto de 2018.

\section{Resumen}

En mi disertación de 1985, Early Israel, ofrecí la siguiente máxima: nuestra más importante tarea es reconocer nuestra ignorancia. El concepto de "antiguo Israel" fue inventado por la historiografía moderna como una manera de organizar todo lo que los investigadores creían conocer sobre la sociedad de la Palestina antigua y su historia. Más de veinte años atrás, Philip R. Davies definió al "antiguo Israel" como la manera en que la información histórica del antiguo Levante era mezclada con relatos bíblicos sobre Israel en algo que solamente existía en la mente de los biblistas. Ello nos remite al discurso de Platón sobre la memoria humana como una tablilla de arcilla fresca sobre la cual se escribe. Podríamos sustituir hoy esta tablilla de arcilla con un disco blando. Pero, lo esencial es que una vez construido, el concepto de "antiguo Israel" ha servido como el disco blando/tablilla de arcilla sobre el/la cual se ha escrito toda la información -mítica, histórica- del mundo antiguo para luego ser integrada con la información bíblica. En una discusión más precisa sobre la memoria, podría decirse que el antiguo Israel es algo "memorizado". Se indica en ocasiones que el antiguo Israel recordaba algo. De este modo, en efecto, una memoria creada por la moderna investigación se transforma en el sujeto que recuerda, y así los investigadores simplemente asumen que ellos conocen mucho más de lo que en realidad pueden conocer.

\footnotetext{
* Paper originally read in a session on cultural memory at the European Association of Biblical Studies annual meeting in Amsterdam, July 2012. The article has not been rewritten for publication here, but notes were added with updated bibliography.
}

Palabras clave

"antiguo Israel" Antiguo Testamento memoria cultural historiografía 


\section{Keywords}

"ancient Israel" Old Testament cultural memory historiography

\begin{abstract}
In my dissertation from 1985, Early Israel, I presented the following maxim: Our most important duty is to acknowledge our ignorance. The concept of "ancient Israel" was invented in modern scholarship as a way to organize everything these scholars believed to know about ancient Palestinian society and its history. More than twenty years ago, Philip R. Davies defined "ancient Israel" as the way historical information from the ancient Levant was blended with biblical stories about Israel into something that only existed in the mind of biblical scholars. This reminds us of Plato's discourse about human memory as a soft tablet of clay to be inscribed. We might substitute his clay tablet with a "soft disc." But the essential is that once constructed, the concept of "ancient Israel" has served as the soft disc / tablet of clay on which to inscribe all information -mythical, historicalfrom the ancient world after which it was blended with biblical information. In a more narrow memory discussion, it may be said that ancient Israel is something "memorized." It is sometimes said that ancient Israel remembered something. As a matter of fact, in this way a memory created by modern scholarship becomes the subject that remembers, and in this way the scholars simply assume that they know far more than they are indeed able to know.
\end{abstract}

\section{Ancient Israel}

Towards the end of my dissertation from 1985, Early Israel, I formulated a couple of axioms. The first was: Our most important duty is to acknowledge our ignorance. The second stated: Once we have acknowledged the state of our ignorance we are in a position to acknowledge what we really do know (Lemche, 1985: 414). The late Robert Carroll wrote me a letter in which he claimed that this was the most important that was said in Old Testament studies in a hundred years.

These axioms were formulated when biblical studies were in the middle of a change of paradigm, from classical historical-critical scholarship to what William G. Dever once described as the post-modern malarkey (Dever, 2000). Early Israel definitely belonged among the historical-critical studies of the history of Israel, although it introduced in a serious way the consequences of sociological history. However, when I finished that study it had created a personal vacuum: It was no so much that one hypothesis about the origins of Israel was substituted by another one but it had to do with the realization that this was not about changing hypotheses and models, it was much more fundamental: It was the realization that nothing fitted. The discrepancy between biblical historiography relevant to the history of early Israel was not something that appeared here and there, it was a systemic lack of agreement. By "systemic" I mean something intended, saying at the same time that biblical historiographers were formulating a distinctive program of their own without any consideration of what may really have happened and what may never have happened. The description of the early history of Israel had nothing to do with what happened in Palestine during the transition between the Late Bronze Age and the Early Iron Age. It was a reflection of a group of historiographers from another time 
putting together a program for their and their society's own future. It was definitely a history about what was going to happen and not a history about what had happened.

So far we were only talking of early Israel. In 1985, Israel's prehistory and especially the patriarchs were so-to-speak "history", meaning a thing of past scholarship. ${ }^{1}$ However, it was not to end here. Soon the controversy about the existence of a Davidic kingdom broke loose, an issue already inaugurated by Giovanni Garbini in his Storia e ideologia nell'Israele antico from $1986,{ }^{2}$ but speeding up with the reinterpretation of the archaeological material from Jerusalem that took place in the 1990s. ${ }^{3}$ Before the turn of the 20th century, there was no more a Jerusalem to be dated to the 10th century BCE, the alleged time of David and in total conflict with the normally dating of his kingdom, or even empire, to the 10 th century BCE. During the first ten years of this century, it has become clear that every biblical period, including the time of the Judges, the Monarchy, the Exile and the Persian Period, represents an ideologically constructed history, and the consequences were made clear by Mario Liverani in his Oltre la Bibbia (Liverani, 2003). The history, as we find it in the Old Testament is an invented history which only faintly resembles the real history of the country. Liverani's only weakness is that he as an outsider to the field may accept too much of the biblical historiography as historical: in many ways his real history includes too much of the biblical story. Otherwise he has indicated how to proceed with the project of a history of Palestine in ancient times by forcing us to reevaluate our sources as found in the Old Testament. In itself this is a classical procedure of the historians, really source criticism as recommended by Gustav Droysen (1808-1884).

The next steps in the deconstruction of biblical historiography will have to include the very concept of Israel, first and foremost the idea that Israel from ancient times also included Judah, or that the Judeans understood themselves to be Israelites. The second step will in a serious way have to question the likelihood that biblical narrative belongs to the Palestinian world, especially the idea that it arose in Jerusalem, say in the Persian period, when according to some archaeologists - notably David Ussishkin (2006)- there hardly was a Jerusalem in the Persian Period worth mentioning. In the early Hellenistic Period the centre of the country was definitely Samaria and Gerizim where the remains of a considerable city have been excavated during the last twenty years (see Magen, 2008a, 2008b).

In 1992 Philip Davies published his "down-with-everything book” In Search of Ancient Israel, directly inspired by his stay in Milwaukee together with Thomas Thompson a couple of years before and a long night's discussion with me at the roof of Casa del Valdesi in Rome in the Summer of 1991, where the subject was: Can there be an Israel if there are no Canaanites, the consequence of my study from 1991 The Canaanites in History and Tradition? (Davies, 1992; Lemche, 1991). The most important part of Davies' book is without doubt his distinction here between three different Israel's: Historical Israel, Biblical Israel, and Ancient Israel, a logical distinction that should always be kept in mind.

Historical Israel has to do with the fact that historical records tell us that there once was an Israel in Palestine. Mernephtah's stele says so, and also the Mesha
1. The demise of the age of the patriarchs was caused by two studies by respectively Thomas L. Thompson (1974) and John Van Seters (1975).

2. Translated into English as History \& Ideology in Ancient Israel (1988). See especially “David's Empire” (pp. 21-32). 3. An overview of the discussion was presented by Jane M. Cahill, Israel Finkelstein, David Ussishkin, and more in Vaughn and Killebrew (2003), Part 1: “Jerusalem During the Reign of David and Solomon” (pp. 13-180). 
4. I made my final statement as far as the Tel Dan Inscription is concerned in Lemche (2003). No new arguments have changed my mind, and will hardly be able to do so as long as the observations made by R. Gmirkin (2002) have not been addressed.

5. Compare Grabbe (2007) to Kitchen (2003), or perhaps less provocative (although it is the same matter) to the Israel of Provan, Long, Longman III (2003).
Inscription and most likely the Assyrian report on the Battle at Qarqar (ANET, 278). Israel also appears on the Tel Dan inscription, but I still have problems using this as a historical source. ${ }^{4}$ I also believe (pace Thomas Thompson) that it is a safe assumption to argue that this Israel -whatever it was- had its home somewhere between Jerusalem and the Jezreel Valley, and that in the 9th century its capital was Samaria. As a matter of fact this Israel is not very problematic.

Then we have biblical Israel, in Davies opinion the Israel that appears in various disguises in Old Testament literature. Neither is this Israel very problematic. There are different variations of this biblical Israel. The Israel of the Tetrateuch is not necessarily one hundred percent identical with the Israel of Deuteronomistic literature (irrespective of we are accepting the idea of a Deuteronomistic History in line with Martin Noth, or have a more fragmentary view on this literature as found in several modern studies, including studies by a scholar like Thomas Römer [2007]). It is also from a historian's point of view interesting that the Israel of the last part of 1 Kings and 2 Kings is not far removed from what we know of historical Israel. The Israel of prophetic literature from Amos to Proto-Isaiah may also find a place here. There is no iron curtain between the various Israel's. However, in the shape of "the people of God", we do not talk any longer of a historical Israel: It is the Israel of biblical narrative, and it will be up to future scholarship to sort out what is in biblical narrative historical Israel and what is biblical Israel alias the people of God.

Ancient Israel: The most challenging part of Davies' three Israels. It is the Israel created by biblical scholarship over the last two centuries. It is a mixture of historical Israel and biblical Israel, and an Israel that only exists in the mind of biblical scholars, of course in many different forms: There is a considerable difference between the ancient Israels of say Lester Grabbe's or Kenneth Kitchen's. ${ }^{5}$ The term "ancient Israel" is used in many different ways -thus both Lester Grabbe and I have published books having Ancient Israel as their title (Lemche, 1988) - and Davies's definition seems most often to have been forgotten. However, there is no doubt that critical scholars can distinguish between biblical and ancient Israel. It is less clear that they understand the difference between historical Israel and ancient Israel. Ancient Israel seen as the result of critical historical investigations that began more than two hundred years ago is a scholarly constructed Israel. It never existed except as this scholarly concept. It is so-to-speak the cultural memory of biblical scholars in modern times.

Now, it is in every scholarly discipline the scholar's first duty to be clear about definitions. Without such a clarification, everything ends up in a terminological morass. At the present, my favorite line is by Ehud Ben Zvi (2011: 13) in an article published recently within the The Centre for Bible and Cultural Memory (University of Copenhagen) context: "There is no doubt that by the later Persian/Hellenistic period the figure of Abraham played a prominent role in the memory of ancient Israel". Ancient Israel is itself a memory, but how can a memory remember, the memory of a memory! There never was in ancient times anything that was called "ancient Israel." It is a definition created by modern scholarship as the critical opponent to biblical Israel. Ancient Israel has no memory. 
Now, we have two ways to proceed because we are really placed in front of two sets of interlocked cultural memories, on one hand biblical Israel, and on the other ancient Israel. Historical Israel has no part in this. Historical Israel is the subject of a secular investigation into the history of the landscape of Palestine in antiquity. But I will return later to this part of the discussion.

Logically we will have to begin with biblical Israel, the natural point of departure, because without this biblical Israel there would be no ancient Israel. So, the opening question should be: Biblical Israel: Whose Israel? Yes, it is the Israel of the writers of biblical literature. But who are we talking about? Remember that asking a question like this, ancient Israel should not interfere. Ancient Israel is not ancient at all, it is modern imagination. However, the answer may be answered if you skip the idea of naming these authors. They all belong to what Ehud Ben Zvi has constantly termed the literati, the literary segment of the male population (women normally didn't read or write in those contexts), less than 10 percent, perhaps not even 5 percent. What people not belonging to this stratum thought of "Israel" is unknown. There is no way we can reconstruct memories belonging to people who could not express themselves in writing, not even the elite, alias the ruling class. It is, however, interesting that as late as the Hashmonean period, Hashmonean rulers seem never to have adopted the title "king of Israel" or "regent of Israel," but referred to themselves as leaders of חבר היהודים, "the council of the Jews", an expression found on Hashmonean coins. ${ }^{6}$

The literati are members of a self-contained group, and biblical Israel is their Israel and belonged to nobody else. They constructed their Israel along the lines of cultural memory. As I said, we don't know their identity but that is probably also the only thing we don't know. We know what they wrote and are therefore able to say quite a bit about their background, since they mixed together Oriental -both Mesopotamian, Egyptian, and Syro-Palestinian cultural elements- and Greek cultural traits. Although it has been stated recently that most is Greek or influenced by the Greco-Hellenistic world, I would not leave out oriental traditions; after all these persisted to the end of Greco-Roman rule and were absorbed into the growing Islamic tradition. It is also clear from the inclusion in the collection of biblical books that they knew the oriental wisdom literature and modeled their "wisdom" according to ideas current in the oriental world. After all the excerpts from Amenemope's Wisdom in Proverbs did not come via Greece. ${ }^{7}$

This means that our literati were educated people, not belonging to some backwater society situated in remote nooks and corners in the mountains of Palestine. They would have worked and composed their biblical literature in cultural centers in the Persian and even more likely the Hellenistic world. Only a very romantic and very naive understanding of culture will have objections to these observations. Although Amos is said to be a shepherd (Amos 1:1), the person who put his book together was definitely not a shepherd.

So, which strategies did these literati employ to paint their image of biblical Israel? One could here very well use some of the strategies formulated in Paul Connerton's How Societies Remember (1989), although the title is not very
6. On the name and identity of Israel, see Lemche (2017).

7. I have before warned against a too automatically acceptance that everything in the Hebrew Bible is "Greek". Cf. also Lemche (2016). This does not mean that the Old Testament is not a collection originating in the Hellenistic Period, but allows for accepting the roots of much of the content in the Middle Eastern world at large. 
8. Thus in Lemche (2008: 248). Basic discussion on the phenomenon of ethnicity, Lemche (1998: 8-20), and on language, Lemche (1998: 111-113). precise as societies do not remember anything; they are told what to remember. However, the three elements belonging to the classical definition of ethnicity found in Herodotus (Histories VIII, 144), are employed, although one of them, the language, has been substituted by another one, the land, in itself also an indication of where to look for our literati. First of all we find the idea of a common blood: The literati unfolded this concept in two ways, first by presenting an universal history as found in other Hellenistic historiography, then by singling out one specific person, Abram/Abraham, as the apical ancestor of their own people, the Jews. Biblical Israel had common blood with all the mysterious associations that goes with this concept. Common blood is a metaphor for what keeps a society united, and deviations from the common and accepted pattern is in this way not only a departure from the norm, it is unnatural behavior, even treason. Then every member of this biblical Israel shared a common religion, dictated to them by their God, Yahweh, who had bound Israel to himself by a covenant. Again some very strong metaphors are in use, including that of the covenant which was a fundamental part of the constitution of ancient patronage-organized societies. Breaking with the common blood and the common religion (or: covenant) meant that the person who did so had no part in the society any longer and was expected to be killed, best like Kora, Datan, and Abiram by God himself (Numbers 16), or else by members of his own society. How serious covenants were interpreted in the ancient Near East can be seen from the way Nebuchadnezzar dealt with his unfaithful vassal, Zedekiah. In 597 BCE, Nebuchadnezzar conquered Jerusalem for the first time and removed its king Jehoiachin, who was taken to Babylon and kept there with his family in a kind of golden cage. Nebuchadnezzar had no problem with Jehoiachin, who was not his but Pharaoh's vassal and had not broken any covenant with the Babylonians. Zedekiah was Nebuchadnezzar's personal vassal, and he broke his oath and was treated most cruelly in accordance with the stipulations of that oath. Breaking a covenant with God was not something people just did. It was supposed to bring death and destruction over their heads. Death penalty for breaking with your God(-father) is not something invented by Islam, it certainly is demanded also by biblical literature, as it is the common penalty in patronage organizations whether divine or human like the mafia.

Then it was argued that Herodotus' talk about language as part of ethnicity was not followed by biblical writers. Instead they introduced as the third element in their definition of Israel the concept of a common land. Without a land there will be no people. I have in other places said that this is a natural consequence because the biblical Israelites spoke a language shared with other people. ${ }^{8}$ The writers make no fuss about having their heroes communicating freely with foreign people, including Egyptians (Pharaoh) or people from Mesopotamia such as Laban. But the idea of a land exclusively belonging to the Israelites as a gift from their common God, that is something special only found in biblical literature. In the Old Testament quite a lot of energy is invested in the descriptions of this land of Israel, sometimes even in conflict as when it is debated whether or not the Israelite territories east of the Jordan river were really part of the land of God. Many details are generalized but it would not be too difficult to draw a rough sketch of the geography of Palestine based on geographical information in the Old Testament. After all, Negev is not in Galilee, and Dan is not confused with Beersheba. 
One point is important: This is the country exclusively given to the people of God, but many other peoples are living here including the ghosts of old nations such as the Rephaim. This is representing disorder because these people do not belong to the people of God, and will have to go, voluntarily or by force (eventually killed: Remember, a good Canaanite is always a dead Canaanite). So a new aspect is introduced: The land of Israel, being God's own country, must be kept clean in every meaning of this world, secular as well as religious. However, the story told about Israel in its land was certainly not a salvation history as formulated by Gerhard von Rad (cf. Lemche, 2008: 345-347), it was rather an "unglücksgeschichte", a history of disaster as argued by Franz Hesse. ${ }^{9}$ Israel had in the days of its kings polluted the country of God and was exiled because of that in order that the land would become clean again. It is like in ancient times, when the patriarch Jacob -renamed Israel- and his sons moved to Egypt in a voluntary exile as a punishment for having polluted their country by transgressing the laws of brotherhood, i.e., ignoring the meaning of a common blood. Now the Israelites were removed to Babylon to let the country of God have its Sabbaths, i.e., to allow the country to be purified. Only then it was time to return

In this way, the tales about the exiles became foundation stories. On the other hand, Israel was not the only people in Antiquity that changed place as a part of its foundation stories. As a matter of fact, this was really an idea shared by almost every literati of the Greek-Hellenistic world, including also the Romans who created the story of how they descended from refugees from Troy, as found in Vergil's Aeneid (I am not so sure that old Cato would have been very happy about tracing his origins to a foreign country and foreign people). ${ }^{10}$ Every Greek city had stories about how its population came from another place, whether placed in Greece, in Asia Minor, in Graecia Magna, or in other places in the Mediterranean world. ${ }^{11}$ The only exception was Athens that claimed to be autochthonous, but was also teased by the other Greek states, because in that case the Athenians were not Greeks but Pelasgians, by then considered the original population of Greece. The story is the same in the Old Testament, but the setting is different. In the case of the patriarchs God intervenes and ask Abram to go to Canaan, but that also happened to Aeneas, who were told by the gods to bring his family from Troy to a country that should be his, and also safeguarded by the gods to continue his journey until he reached his destination.

Now a new society also needs a constitution. This was common in Greek societies where the city's law might be found inscribed at the entrance to the city (the well-preserved laws of Gortys of Crete being an obvious example). Without law, there can be no society, as expressed in the famous opening line of Valdemar the Conqueror's Jydske Lov ("the Code of Jutland") from 1241: in Danish, "Med lov skal land bygges" ("the law is the building block on which to build a land/society"). There is no doubt that the law of Moses is understood as the constitution of the people of God, and furthermore, this law was dictated to Israel via Moses by God himself. It is a divine constitution for a holy people and a holy country and thus formulating the conditions for preserving the people and country as holy. It is not ancient oriental law, or for that matter a Greek or Roman one, although certain parts of it definitely has an oriental background and can be compared with, say Gortys' laws, but it is
9. Cf. Hesse (1971), and Lemche (2008: 347-348). On the tragic mode of writing the history of Israel, cf. Nielsen (1997).
10. Vergil's Aeneid was written between 29 and 19 BCE, in order to become the national epic telling the story of Rome's origins.

11. Such stories about origins are found practically everywhere in Hellenistic-Roman literature such as the geographical works of Pausanias (ca. 110-18o CE),

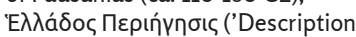
of Greece), and in the extended

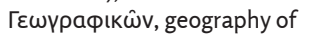
Strabo (ca. 63 BCE to 24 CE). 
12. For an original view of the Law of Moses as influenced by Plato's Laws, cf. Gmirkin (2017).

13. On this issue, Hesse and Wapnish (1997). See also the discussion in Faust (2006: 35-40). predominantly religious in the way that it regulates -or try to- every aspect of the life of a member of the people of God. In this way the biblical laws creates a universe of its own, testifying to the religious character of the society, whose constitution biblical law is supposed to be. ${ }^{12}$

The members of the people of god must be able to distinguish themselves from other people physically. Every secret organization has its sets of signals, whether ancient ones or more recent like the freemasons who have means of signaling to other persons that they belong to this organization. The predominant physical signal is of course the circumcision, although its use may have be limited as the custom was also known among other peoples of the ancient Near East. Thus we find clear evidence in Egypt where illustrations of the act are found in tombs. In Palestine, it seems likely that the habit of circumcision was not unknown, although the Philistines according to biblical narrative were not. Whether this is true or not is not very important. What is important that it is a shared custom, although it is emphasized that it marked the Israelites out. Being circumcised and living in the land of God are meaning the same, and it would be polluting the country if that was not the case. However, at one point biblical circumcision differed from the habit of other people because it was executed on very young boys whereas in other cultures it belonged to the rites de passage of half grownup males. Whoever invented this mess of a tradition supposed to be unique but shared with other people may have lived in a place where nobody except the chosen few were circumcised, maybe in Mesopotamia. In Palestine it makes little sense except if the population at large was Jewish. In this case it could be a way of marking out the foreigners, especially Greek ones, or a casual guest from Mesopotamia, but it would be of no help if an Egyptian visited the country.

Foodways are another way of establishing ethnic difference. The Old Testament mentions the unwillingness of the Egyptians to share their meals with the Hebrews. True enough, the Old Testament includes several laws prescribing a special diet for Israelites, such as eating meat without blood, and prohibitions against consuming meat boiled in milk, meat from pigs, and several similar rules. This is not the place to discuss the appearance or non-appearance of pig bones in excavations in Palestine. ${ }^{13}$ It is only the meaning of the prohibitions as creating a special marker for a special people which is interesting in this context.

One more element is included, the biblical authors use of the concept of les lieux de mémoire, coined by Pierre Nora (1996) in his reinterpretation of the antique rhetorical device of loci memoriae. In several places we have the so-called "etymological narratives" evidently included to explain the name of a certain locality, but it is a device contributing to memory and allied to the passages especially in Deuteronomy encouraging a father to remind his son of the past of his people thereby cementing the child's belonging to the Jewish people. The Pesach seder falls within the same category, and the Easter legend as found in Exodus may have been put together from the very beginning with the celebration of the Jewish pesach in mind, very much as seen by Johannes Pedersen, some eighty years ago (Pedersen, 1960 [1934]: 549-555). 
All together all of this helps to establishing a special and holy and very exclusive identity for the people of God, biblical Israel. The list is not complete, of course, but enough has been said to make it clear that the people of God is understood to be something special, a chosen people, different from other people.

\section{Ancient Israel in Modern Times}

Now how can it be that this ancient construction of a divine society has survived in modern scholarship as the governing model of understanding ancient Palestinian history? It is really quite easy to answer: Because ancient Israel is part of the cultural memory of modern biblical scholars who mostly have, as argued a few years ago by Hector Avalos, a religious background.

Most biblical scholars grew up in a religious context. Look at the composition of students at the theological faculties. The biggest group comes from religious homes, consisting of sons and daughters of ministers, lay preachers, and all other sorts of religiously engaged parents. From early childhood the biblical story and biblical personalities have been part of their life, at home, in church or in the Sunday schools. We may call it indoctrination, but all education whether religious or secular represents indoctrination. As it is argued by students of cultural memory, history is a weapon of mass instruction. This history can be religious, or it can be national, or both at the same time.

Now, since Plato "invented" the soft disc, claiming that human memory is like a soft piece of honey on which memories are impressed, it has been a general assumption that memory constitutes identity. Removing a person's memory means removing his identity. Nobody wants to lose his identity without a fight. It is a fight for life and survival. When the stories of the Bible has been taught to young people, it becomes part of their personal memory, and therefore part of their identity. Then it is not very important whether they chose to belong to a liberal part of the official church or synagogue, or to some more or less fundamentalist, sectarian part of their religion.

We saw how this found an expression in the conflict more than a generation ago between on one side William Foxwell Albright and his students such as John Bright and George Ernest Wright, and the German tradition of scholarship in those days embodied in the shape of Albrecht Alt and Martin Noth and their students (cf. Long, 1997: 15-70). Basically the two schools were in absolute agreement. Both promoted ideas of ancient Israel that stayed within the structure of biblical historiography. The only difference was the degree of paraphrasing of the Bible present in their analysis. It was to those living at that time clear that the Americans were more conservative than their European colleagues, but it only had to do with how much of the detail found in biblical literature that was kept and how much that found a different -revised-form. Most of the controversies between these companies of scholars related to pre-monarchical Israel. From the time of Saul and David they were amazingly in agreement, and very little separated them. 
14. The clearest example of this strategy is found in Albright (1949).

15. The Israelite amphictyony was proposed by Noth in Das System der zwölfStämme Israels (1930), and his discussion of the patriarchs as part of the traditions nourished by this amphictyony can be found in his Geschichte Israels (1954: 114-120).
This becomes obvious when we review the debate about Israel's origins. The Americans using biblical archaeology as their preferred tool, introduced a model of conquest not far removed from the version found in the Book of Joshua. ${ }^{14}$ The German school paid less attention to archaeology (although it would be ridiculous to argue that scholars like Alt and Noth knew less about archaeology than the Americans). Both were directors of the German School in Jerusalem, and substituted conquest with immigration (although scholars should know that the impression is modified a little if one reads Alt's second article about the Israelite immigration from 1939, not translated into English; cf. Alt, 1953a [1925]; 1953b [1939]). Both schools agreed on the essentials: Israel was a foreign people that came to Palestine at the end of the Late Bronze Age. Then it was really a minor matter -but not perceived as such-if the Israelites claimed the land as theirs as a result of a violent conquest or after have lived in the country for a number of years slowly pressed the original population, the Canaanites, out of the country.

The situation when it came to the Patriarchs was a little different because the Americans still believed in their historicity, while the Germans -following the lead of de Wette from the beginning of the 19th century-considered the stories about the patriarchs a part of Israel's oldest traditions, something kept alive in the Period of the Judges at the religious centers of the amphictyony, a construct by the same German scholars. ${ }^{15}$ However, both parts were in total agreement as to the amphictyony understood to be a sacral league of the twelve Israelite tribes which existed before the introduction of the Hebrew monarchy. If anything John Bright's concept of the league was even more marked than the original formulation by Noth (cf. Bright, 1960: 128-160).

In an important article, "Nuovi sviluppi nello studio della storia dell'Israele biblico", Mario Liverani argued for understanding modern historical studies of ancient Israel as contributions to a hyperstory, meaning that each new history of Israel was as a matter of fact written on the pages of the previous (Liverani, 1999). We might really talk about a palimpsest, a manuscript being overwritten by another text. Every new history of ancient Israel stood on the shoulders of its predecessors, and ultimately they were all late expressions of the biblical narrative, bringing it up to what they believed to be modern standards.

As nobody voluntarily parts with his cultural memory, any attack on the accepted cultural memory of biblical students must be seen as a threat to the survival of the cultural memory, it is the identity of the people believing in this cultural memory and basing their lives on its acceptance as a valuable story from the past. The willingness to substitute this memory with something which historians have reconstructed has been almost non-existent. The consequence of this sticking with the stories from the past as told by your parents became more serious as biblical stories were turned into historical sources about what happened in the past, a natural consequence of the changes in the concept of history over the last two centuries. When "truth" became identified as "historical truth", i.e., nothing represented "truth" if it had not happened in the secular world, any talk of a truth that was dependent of the content of the narrative and not of events that may or may not lie behind these stories was either rejected out of hand or ignored. Scholarly contributions not supporting the basic 
historical "truth" of biblical narrative were seen as attacks on western identity, including modern Israeli self-identification, and therefore as dangerous and to be avoided. Many here today probably remember the rhetoric of William G. Dever, himself a son of a lay preacher, whose identity was based on biblical narrative. ${ }^{16}$

It would be interesting if somebody would one day take up the assignment to write a story of biblical scholarship during the last hundred and fifty years, The Rise and Decline of Biblical Scholarship. I did one, covering the time from Julius Wellhausen to Rudolf Kittel, showing how even Wellhausen's students contributed to the "normalization" of scholarship after their revolutionary (Doktor-) father (cf. Lemche, 2013). However, over the last two generations the discovery of the clear discrepancy between what is told in the Bible and what happened in real life has forced critical scholars to question as historical almost everything told by biblical historiographers. First it is necessary to part with the concept of ancient Israel as if it represented a historical fact and not modern cultural memory. Then it becomes necessary to realize that it is likewise questionable to use the concepts of "Israel" and "Israel's history" in the way it has been done for several hundred years. Ancient Israel only survives as part of modern cultural memory. It never was. Israel was never used as a name of Palestine in ancient times, but only in the biblical narrative as a name for the people of God. As a matter of fact, the first reference to Israel as a political concept may be the way Bar-Kochba named himself as נשא ישראל, although it is clear that also his adoption of this title was based on the biblical use of the term "Israel" (cf. Lemche, 2017: 83). Historical Israel never covered more than a fraction -sometimes a major one, sometimes not very impressive- of Palestine. Studying the history of this Israel and comparing it with the study of the minor landscape of Judah to the south of Israel is like studying the history of Palestine in the Amarna Age, when the opponents were Labaya of Shechem and Abdi-Heba of Jerusalem, Abdi-Heba who after Labaya's death was described by another Palestinian notability as a new Labaya "who takes away our land" (by Šuwardata, EA 280:30-35). Israel is best understood within the context of the dichotomy of central Palestine, something that existed until modern Israel occupied Judea and Shomron in 1967 and caused both the northern and southern part of the central Palestinian highlands to unite in resistance to the new intruders. Before that the people in Hebron never liked the people in Nablus and vice versa.

From a historical point of view, our knowledge of historical Israel is limited in extent. Giving up the biblical story is the same as accepting how little we know. Keeping ancient Israel as our point of reference means that we know far more, or believe that we know far more than we really know. But summing up: if we don't admit what we do not know, we have not a chance of knowing what we know. The consequence of the blind acceptance of the stories about biblical Israel transformed in our context to ancient Israel is that we also ignore the little we really know about historical Israel. A consequence of the silencing of Palestinian history, meaning that the history of the country is almost exclusively seen through the lenses of biblical authors, will be that most people in our field will not be able to accept what is about to come out as a non-Jewish history of Palestine, something being formed in the occupied territories. As the Israeli newspaper Hairetz once regretted, the Palestinian historians are writing the
16. William G. Dever has written about his own upbringing in a fundamentalist Christian environmen in the preface to his Did God Have Wife? (2005: x-xi). The topic (including the phenomenon of Dever) was a main issue in Hector Avalos' The End of Biblical Studies (2007). 
Jews out of the history of their country, something which may actually happen. The acceptance that as cultural memory the biblical story in its modern disguises has become a way to construct a society, may be counterbalanced by another story meant to construct identity, in this case a Palestinian identity that ignores Israeli identity. Whether or not this is good for anything is a political issue not relevant to the present context. 


\section{Q Bibliography}

» Albright, W. F. (1949). The Archaeology of Palestine. Harmondsworth, Penguin Books.

»Alt, A. (1953a). Die Landnahme der Israeliten in Palästina [1925], in: Alt, A., Kleine Schriften zur Geschichte Israels I. München, C.H. Beck'sche Verlagsbuchhandlung: 89-125.

" Alt, A. (1953b). Erwägungen über die Landnahme der Israeliten in Palästina [1939], in: Alt, A., Kleine Schriften zur Geschichte Israels I. München, C.H. Beck'sche Verlagsbuchhandlung: 126-175.

» ANET = Pritchard, J. B. (ed.). 1969. Ancient Near Eastern Texts Relating to the Old Testament. Princeton, Princeton University Press, 3rd edn.

»Avalos, H. (2007). The End of Biblical Studies. Amherst (NY), Prometheus Books.

»Ben Zvi, E. (2011). The Memory of Abraham in Late Persian / Early Hellenistic Period Yehud, in: Carstens, P. and Lemche, N. P. (eds.), The Reception and Remembrance of Abraham. Piscataway (NJ), Gorgias Press: 13-60.

»Bright, J. (1960). A History of Israel. London, SCM Press.

"Connerton, P. (1989). How Societies Remember. Cambridge, Cambridge University Press.

"Davies, P. R. (1992). In Search of “Ancient Israel". Sheffield, Sheffield Academic Press.

»Dever, W. G. (2000). Save Us from Postmodern Malarkey, in: Biblical Archaeology Review 26/2. Electronic version: http://cojs.org/save_us_from_postmodern_ malarkey-_william_g-_dever/

»Dever, W. G. (2005). Did God Have Wife? Archaeology and Folk Religion in Ancient Israel. Grand Rapids (MI), Eerdmans.

» Faust, A. (2006). Israel's Ethnogenesis: Settlement, Interaction, Expansion and Resistance. London, Equinox.

» Garbini, G. (1988). History \& Ideology in Ancient Israel. London, SCM Press.

» Gmirkin, R. E. (2002). Tools Slippage and the Tel Dan Inscription, in: Scandinavian Journal of the Old Testament 16: 293-302.

» Gmirkin, R. E. (2017). Plato and the Creation of the Hebrew Bible. London, Routledge.

"Grabbe, L. L. (2007). Ancient Israel: What Do We Know and How Do We Know It? London, Bloomsbury, rev. edn. 2017.

»Hesse, B. and Wapnish, P. (1997). Can Pig Remains Be Used for Ethnic Diagnosis in the Ancient Near East?, in: Silberman, N. A. and Small, D. (eds.), The Archaeology of Israel: Constructing the Past, Interpreting the Present. Sheffield, Sheffield Academic Press: 238-270.

» Hesse, F. (1971). Abschied von der Heilsgeschichte. Zürich, TVZ Verlag.

» Kitchen, K. A. (2003). On the Reliability of the Old Testament. Grand Rapids (MI), Eerdmans. 
»Lemche, N. P. (1985). Early Israel: Anthropological and Historical Studies on the Israelite Society before the Monarchy. Leiden, E.J. Brill.

»Lemche, N. P. (1988). Ancient Israel: A New History of Israelite Society. Sheffield, JSOT Press.

"Lemche, N. P. (1991). The Canaanites and Their Land: The Tradition of the Canaanites. Sheffield, Sheffield Academic Press, 2nd edn 1999.

»Lemche, N. P. (1998). The Israelites in History and Tradition. Louisville (KY), Westminster John Knox Press.

"Lemche, N. P. (2003). 'House of David': The Tel Dan Inscription(s), in: Thompson, T. L. with Jayyusi, S. (eds.), Jerusalem in Ancient History and Tradition. London, T\&T Clark: 46-67.

"Lemche, N. P. (2008). The Old Testament between Theology and History: A Critical Survey. Louisville (KY), Westminster John Knox Press.

"Lemche, N. P. (2013). Rachel and Lea, or On the Survival of Outdated Paradigms in the Study of the Origin of Israel, I-II [1987-88], in: Lemche, N. P., Biblical Studies and the Failure of History: Changing Perspectives 3. London, Equinox: 95-132.

»Lemche, N. P. (2016). Is the Old Testament Still a Hellenistic Book?, in: Hjelm, I. and Thompson, T. L. (eds.), Biblical Interpretation Beyond Historicity. Changing Perspectives 7. London, Routledge: 61-75.

»Lemche, N. P. (2017). A Sectarian Group Called Israel: Historiography and Cultural Memory, in: Crossley, J. and West, J. (eds.), History, Politics and the Bible from the Iron Age to the Media Age. Essays in Honour of Keith W. Whitelam. London, Bloomsbury: 72-96.

»Liverani, M. (1999). Nuovi sviluppi nello studio della storia dell'Israele biblico, in: Biblica 80: 488-505.

»Liverani, M. (2003). Oltre la Bibbia: Storia antica di Israele. Roma-Bari, Editori Laterza [English translation: Israel's History and the History of Israel (transl. by Chiara Peri and Philip R. Davies). London, Equinox, 2005].

»Long, B. O. (1997). Planting and Reaping Albright: Politics, Ideology, and Interpreting the Bible. University Park (PA), The Pennsylvania State University Press.

" Magen, Y. (ed.) (2008a). Mount Gerizim Excavations: A Temple City. Jerusalem, Israel Antiquities Authority.

" Magen, Y. (ed.) (2008b). The Samaritans and the Good Samaritan. Jerusalem, Israel Antiquities Authority.

»Nielsen, F. A. J. (1997). The Tragedy in History: Herodotus and the Deuteronomistic History. Sheffield, Sheffield Academic Press.

»Nora, P. (1996). General Introduction: Between Memory and History, in: Nora, P. (ed.), Realms of Memory, I: Conflicts and Divisions. New York, Columbia University Press: 1-20.

» Noth, M. (1930). Das System der zwölfStämme Israels. Stuttgart, Kohlhammer.

"Noth, M. (1954). Geschichte Israels. Göttingen, Vandenhoeck \& Ruprecht, 2nd edn.

»Pedersen, J. (1934). Israel III-IV: Hellighed og Guddommelighed. Copenhagen, Branner og Korch, 2nd edn 1960.

"Provan, I. W., Long, V. P. and Longman III, T. (2003). A Biblical History of Israel. Louisville (KY), Westminster John Knox Press. 
»Römer, T. (2007). The So-Called Deuteronomistic History: A Sociological, Historical and Literary Introduction. London, T\&T Clark.

» Thompson, T. L. (1974). The Historicity of the Patriarchal Narratives: The Quest for the Historical Abraham. Berlin, Walter de Gruyter.

»Ussishkin, D. (2006). The Borders and De Facto Size of Jerusalem in the Persian Period, in: Lipschits, O. and Oeming, M. (eds.), Judah and the Judeans in the Persian Period. Winona Lake (IN), Eisenbrauns: 147-166.

»Van Seters, J. (1975). Abraham in History and Tradition. New Haven, Yale University Press.

»Vaughn, A. and Killebrew, A. E. (eds.) (2003). Jerusalem in Bible and Archaeology: The First Temple Period. Atlanta, Society of Biblical Literature. 
